\title{
Determination of mycorrhizal developments in pecan nut seedlings inoculated with Tuber aestivum Vittad. (summer truffle)
}

\author{
Sevgin Özderin ${ }^{\mathrm{a}, *}$ (i), Hakan Allı ${ }^{\mathrm{b}}$ (i)
}

\begin{abstract}
Summer truffles (Tuber aestivum Vittad.)are interest of in the world as a promising and encouraging cultivation in rural areas. As it has characterstics of Mediternean ecosystems, it is determined that it contains suitable conditions for the growth of truffles due to ecological factors of Turkey. Tuber aestivum Vittad.(Summer truffles)inoculated Pecan (Carya illinoensis(Wangenh.)K.Koch) seedlings were made to reveal mycorrhizal growth. In conclusion, this research the selection of proper twelve seedlings of pecan is obtain positive results. Pecan nut provides a better understanding hosting for Tuber aestivum. of pecan-associated. This study is important for future research on Pecan nut inoculated with Tuber aestivum cultivation and will be important in terms of using data obtained from Tuber aestivum inoculated with Pecan nut culture studies.
\end{abstract}

Keywords: Summer truffle, Tuber aestivum, Pecan nut

\section{Tuber aestivum Vittad. (yaz trüfü) aşılanmış pikan cevizi fidanlarında mikorizal gelişimlerin belirlenmesi}

\begin{abstract}
Özet: Dünya'da kırsal alanlarda yaz trüflerine (Tuber aestivum Vittad.) yetiştirme açısından ümit verici ve teşvik edici bir yetiştiricilik olarak ilgi duyulmaktadır. Ülkemiz, Akdeniz ekosistemlerinin özelliklerini taşıması nedeniyle trüf mantarlarının yetişmesi için uygun koşulları barındırdığı belirlenmiştir. Ülkemiz ekolojik faktörleri T. aestivum Vittad. yetiştiriciliği için uygun olup ülkemizde birçok bölgede tespit edilmiştir. Bu çalışma, Tuber aestivum Vittad. (Summer Truffles) aşılanmış Pikan cevizi (Carya illinoensis (Wangenh.) K. Koch) fidanlarındaki mikorizal gelişmeyi ortaya çıkarmak için yapılmıştır. Bu araştırmada sonuç olarak Tuber aestivum aşılanan pikan cevizi fidanlarından rastgele seçilmiş olan 12 fidanda olumlu sonuçlar elde edilmiştir. Yetiştirilen Tuber aestivum aşlanmış pikan cevizi fidanlarında pikan cevizinin konukçu tür olarak uygun olduğunu göstermiştir. Bu çalışma Tuber aestivum aşılanmış, pikan cevizi yetiştiriciliği hakkında gelecekteki araştırmalar için önem arzetmekte olup Tuber aestivum aşılanmış pikan cevizi kültür çalışmalarında elde edilen verilerin kullanılması yönünden önemli olacaktır.
\end{abstract}

Anahtar kelimeler: Yaz trüfü, Tuber aestivum, Pikan cevizi

\section{Introduction}

Pecan (Carya illinoensis (Wangenh.) K. Koch) is a hard-shelled fruit belonging to the Juglandaceae family. For pecan nuts which come mainly from North America and are economically valuable, mostly North America, South America, Europe, Asia and Mexico include centers of production and natural distribution areas (Gardea et al., 2011, Thompson and Conner, 2012). Pecan nut is grown commercially in the United States, from Florida to the south, from West to New Mexico.In 2014, the pecan nut production in the US corresponded to USD 517 million (Marzolo, 2015). As pecan fruits in Turkey look like walnuts, they are called pecan walnuts. Studies on dried walnuts that can be utilized in different forms including more than 1000 pecan nut varieties in the world have reported their several positive effects on health (Venkatachalam et al., 2004-2007; Thompson and Conner, 2012). Truffle species are ectomycorrhizal fungi that grow underground and that form mycorrhizae as a result of their symbiotic lives with the roots of several different tree species such as hazelnut (Corylus avellana), oaks (Querqus spp.), beech (Fagus sylvatica), birch (Betula spp.) and Pecan (Carya illinoensis (Wangenh.) and other bush species such as Cistus (Benucci et al., 2012a; Riousset et al., 2001; Chevalier and Frochot, 2002; Stobbe et al., 2012). Truffles are the most economically valuable ones among fungus species. Among truffle species, Tuber magnatum Pico and Tuber melanosporum Vittad. are marketed at top prices in the world's cuisines because of their unique smell and flavor (Donnini et al., 2013). While the prices of truffle vary based on the harvested amount and quality, $T$. magnatum is sold per $\mathrm{kg}$ for between $€ 1200$ and $€ 4000$ (Figliuolo et al., 2013), while Tuber melanosporum Vittad. and Tuber brumale Vittad. are sold respectively for US\$1200 and US\$340 per $\mathrm{kg}$. In the world, saplings that are grown are grafted with Tuber melanosporum, Tuber aestivum Vittad., Tuber borchii Vittad., and T. brumale at plantations for truffle cultivation (Reyna and GarciaBarreda, 2014). One of the main priorities of turf trade is to

\footnotetext{
$\square$ a Muğla Sttkı Koçman University, Truffle Application and Research Center, 48000, Muğla, Turkey

b Muğla Sitkı Koçman University, Faculty of Scinece, 48000, Muğla, Turkey

@ * Corresponding author (İletişim yazarı): sevginozderin@ mu.edu.tr

$\checkmark \quad$ Received (Geliş tarihi): 08.11.2019, Accepted (Kabul tarihi): 25.03.2020
}

Citation (Atıf): Özderin, S., Allı, H., 2020 Determination of mycorrhizal developments in pecan nut seedlings inoculated with Tuber aestivum Vittad. (summer truffle). Turkish Journal of Forestry, 21(2): 131-135. DOI: $10.18182 / \mathrm{tjf} .644385$ 
increase truffle production and development of host species is secondary. The wood of some host species is economically valuable. Truffles also contribute to the development of trees with the help of the ectomycorrhizal function of tree species such as spruce, poplar, pine, pecan and hazelnut (Benucci et al. 2012b). It was determined in hazelnut gardens commercially grown in Spain that $T$. melanosporum and $T$. brumale increased hazelnut production (Reyna, 2007).

Benucci et al. (2012a) describe the mycorrhization of $C$. illinoinensis with $T$. aestivum and $T$. borchii for the first time in detail, and this way, they became pioneers in revealing the mycorrhizal relationship between truffles and pecan nuts (Trappe et al., 1996). In the pecan gardens in North America, truffles estabblish a dominant ectomycorrhizal relationship (Bonito et al., 2011a), Tuber lyonii Butters is the first truffle defined in pecan nuts (Trappe et al., 1996). T. lyonii was then cultivated by inoculation to seedlings at plantations, and its mycorrhization rate was found to be high (Bonito et al., 2012). Pecan nut gardens may be managed to optimize both truffle and pecan nut production, but the $T$. lyonii market is still underdeveloped, and common product production is on an experimental level. Anyway, Tuber lyonii Butters truffle species are regularly cultivated at gardens where pecan nuts are grown in Georgia, Florida, Texas and other southern states of the US (Hanlin et al., 1989; Trappe et al., 1996). While Tuber lyonii is known as a pecan truffle, it also shows a mycorrhizal relationship with other angiosperm host species such as Quercus (oaks) (Heimsch, 1958; Trappe et al., 1996; Jumpponen and Jones, 2010). Although pecan nut trees are cultivated internationally due to their valuable and nutritional contents, as these trees are dependent on various ECM fungi for health and nutrition, this is the second detailed study on this host tree species regarding ECM fungi (Bonito et al., 2011b). Pecan nut (Carya illinoensis (Wangenh.) K. Koch) production is an attractive option for nut, truffle and wood production. It is now known whether or not pecan nut trees in Europe have a mycorrhizal relationship with European truffles.

In this study, we evaluated the potential of using pecan nut as a host species for cultivating Tuber aestivum Vittad. Our specific purpose was to assess whether or not pecan seedlings would form a mycorrhizal relationship with Tuber aestivum.

\section{Materials and methods}

\subsection{Material}

In this study, the seeds of Pecan (Carya illinoensis (Wangenh.) K. Koch) which are the materials of our study, were collected in ripening periods (October-November, 2018) from in plantation of Serik -Antalya $40 \mathrm{~m}$. The obtained seeds were kept in plastic bags in perlite at $\pm 4{ }^{\circ} \mathrm{C}$ for 2 months until the study in the Muğla Sitkı Koçman University, Truffle Application and Research Center.

Ripen ascocarps of $T$. aestivum were collected from different localities Pinus brutia (Ten.) and Quercus sp. forests in Muğla in spring and early summer and, The coordinates stand characteristics of ascocarps were recorded defined and documented (Hall et al., 2007). The soil on the surface of ascocarps were cleaned with brush and water, and the ascocarps that had rotten parts or larvae were removed. Samples were taken from each ascocarp, macroscopic and microscopic examinations were made, and the ascocarps that were suitable for spore isolation were seperated. The selected ascocarps were sterilized with $75 \%$ alcohol (Yuanzhi, 2016), and were put in plastic bags and kept at $20^{\circ} \mathrm{C}$ (Yuanzhi, 2016) until the mycorrhization examinations were made.

\subsection{Method}

\subsubsection{Seed germination}

In the present study, the 300 seeds of Pecan (Carya illinoensis (Wangenh.) K. Koch) were used for the germination. The pecan seeds were kept at warm distilled water for 10 days to swell, and then were sterilized in 5\% hydrochloric acid in plastic container. Then, peat were sterilized in a sterilizer at $121^{\circ} \mathrm{C}$ at $1,5 \mathrm{~atm}$. pressure for 1 hour; and then seeds were left to develop in peat at $20^{\circ} \mathrm{C}$, in 16-hour light cycle and at 50-60\% humidity for 100days. It was determined that 300 of the 235 pcs of (Carya illinoensis (Wangenh.) K. Koch); germinated among these seeds that were placed in germination contained.The plants that were suitable for truffle inoculation (Fischer and Colinas, 1996) Council Directive 1999/105/EC of 22 December 1999) were selected and the others were discarded from the experiment (Figure 1a,1b).

\subsubsection{Sterilization of the pots}

Plastic pots $\left(1,9 \mathrm{dm}^{3}\right)$ were used in the trial, after they were washed with tap water and kept at $10 \%$ HCL solution for 24 hours before the trial, and then were washed again with distilled water.

\subsubsection{Inoculation}

T. aestivum (640 g.) to be inoculated were weighed and with distilled water pured in a blender for one hundred fifty all pecan sampling, in March 2018. Then, agarose/water mixture (6 gr Sigma agarose /21t) was added, and mixed again to obtain a homogenous solution. The randomly selected seedling roots were submerged in the solution to ensure inoculation (Fischer and Colinas, 1996) (Figure $1 \mathrm{~b}, 1 \mathrm{c})$. The inoculated seedlings were planted into the pots with 2lt sterilized peat. One hundred sixty seedlings were inoculated with truffle from Pecan (Carya illinoensis (Wangenh.) K. Koch), and grow (\%50 humidity, daylight, and $25-35^{\circ} \mathrm{C}$ ) for 15 months by applying regular care in groups of 40 seedlings at Muğla Sitkı Koçman University, Truffle Application and Research Center Plantation (Figure 1a, 1b, 1c,1d). 

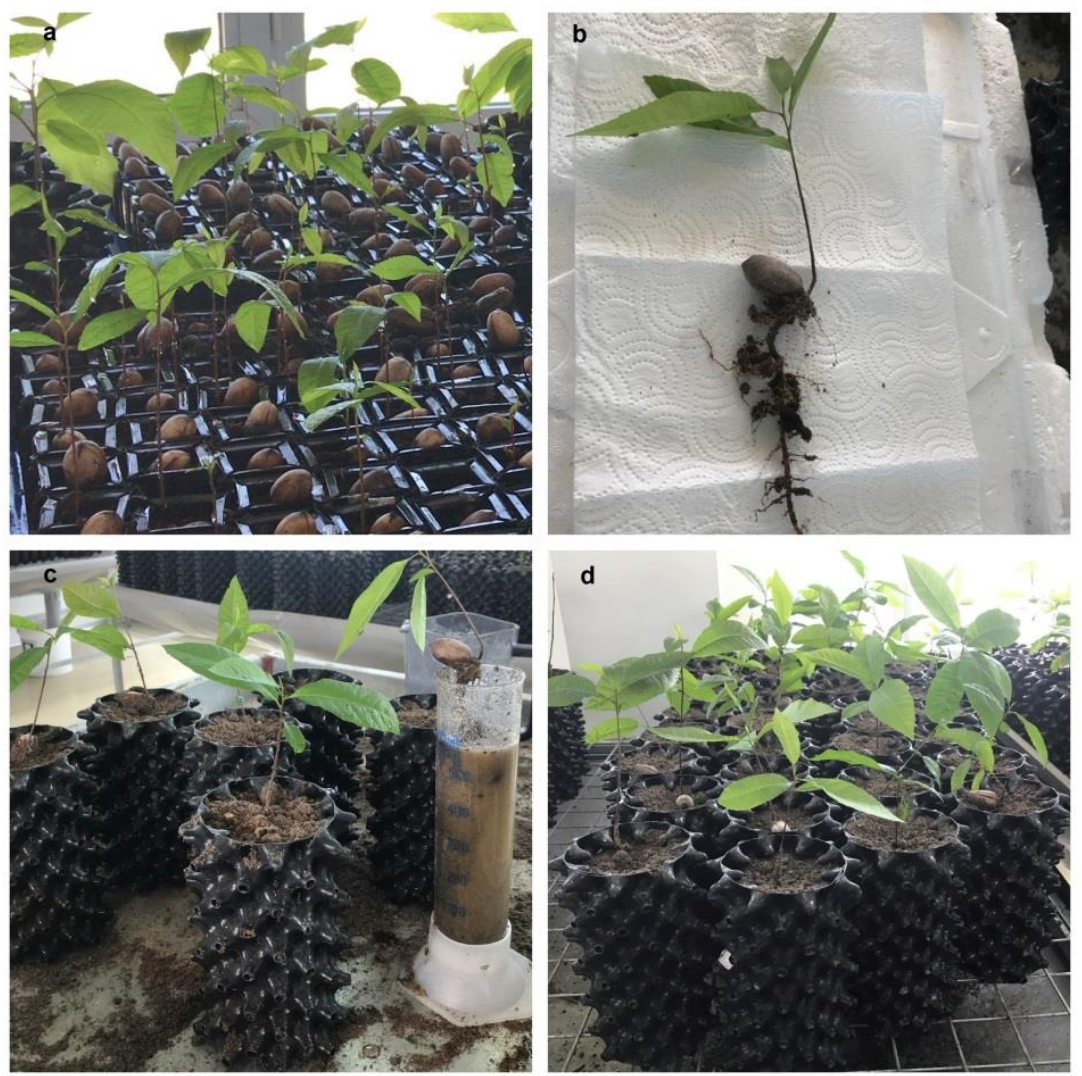

Figure 1. Germination of pecan (Carya illinoensis)in peat (a), pecan (Carya illinoensis) seedlings(b),the solution to be used for the inoculation and the inoculating process (c), the inoculated pecan seedlings left to grow (d)

\subsubsection{Determining the Tuber aestivum Mycorrhiza and identification of the ectomycorrhiza}

After the 15-months growth period, 12 seedlings were randomly selected as 4 from each pecan group and brought to the laboratory. After these saplings were removed from the pots with care, the roots were first washed with pure water to remove the soil layer and then the root pieces taken from each root were cut as $\sim 2 \mathrm{~cm}$ (Fischer and Colinas, 1996; Reyna et al., 2000). The root parts that were cut were placed to petri dishes which had distilled water in them (Avis et al.,2003) and the root parts that had and that did not have mycorrhiza, and that were contaminated (Agerer, 1991) were counted anatomically and morphologically (Zambonelli et al., 1993) under stereo microscope (Olympus SZX7). A total of 250 root parts in average were examined from each plant in the counting process.

\section{Result and Discussion}

Tuber F. H. Wigg. (Ascomycota, Pezizales, Tuberaceae) is a fungus species that is known as "truffle", traditionally utilized famously in the world and produces hypogeous ascomata. Most of these have expensive prices, and they are highly valuable due to their unique flavor and culinary value. Moreover, some of the members of the Tuber genus form symbiotic ectomycorrhiza with gymnosperm and angiosperm forest tree species (Riousset et al., 2001; Selosse et al., 2004; Mello et al., 2006; Trappe et al., 2006; 2009). Additionally, truffles are also significant as they serve as a primary or complementary source of nutrition for soil micro-fauna and some mammalian species (Hanson et al., 2003; Trappe and Claridge, 2010; Schickmann et al., 2012).

The morphological characteristics of $T$. aestivum on pecan nut are similar to those on other host species (e.g. oaks, hazelnut), and its morphologies are in parallel with the previous literature (Özderin et al., 2018)

In this study, by using $T$. aestivum spore solutions, we aimed to determine whether or not $T$. aestivum ectomycorrhiza would form on pecan nut seedlings.

After the 12-14-month growth period, selected 12 seedlings were brought to the laboratory. Then these seedlings were removed from the pots with care, the roots were first washed with distilled water to remove the soil layer. Then $2 \mathrm{~cm}$ pieces were cut from the roots (Fischer and Colinas, 1996; Reyna et al., 2000) and placed in petri dishes with distilled water (Avis et al., 2003). Afterwards, mycorrhizal and contaminated (Agerer, 1991) root pieces were counted anatomically and morphologically (Zambonelli et al., 1993) under the stereo microscope (Olympus SZX7).Mycorrhiza of 12 seedlings were counted and $55 \%$ of these seedlings $T$. aestivum mycorrhiza were counted. It was determined that the rate of mycorrhiza in these seedlings developed and 50\% counted (Figure 2a,2b,2c). In addition, T. aestivum cystitis and mantle surface was found in the examinations (Figure 2d,2e,2f,2g) These results showed that the inoculation with $T$. aestivum on pecan seedlings developed was successful. The remaining $45 \%$ of the reasons for not realizing; contamination caused by inoculation, seedlings and water and environmental factors. 

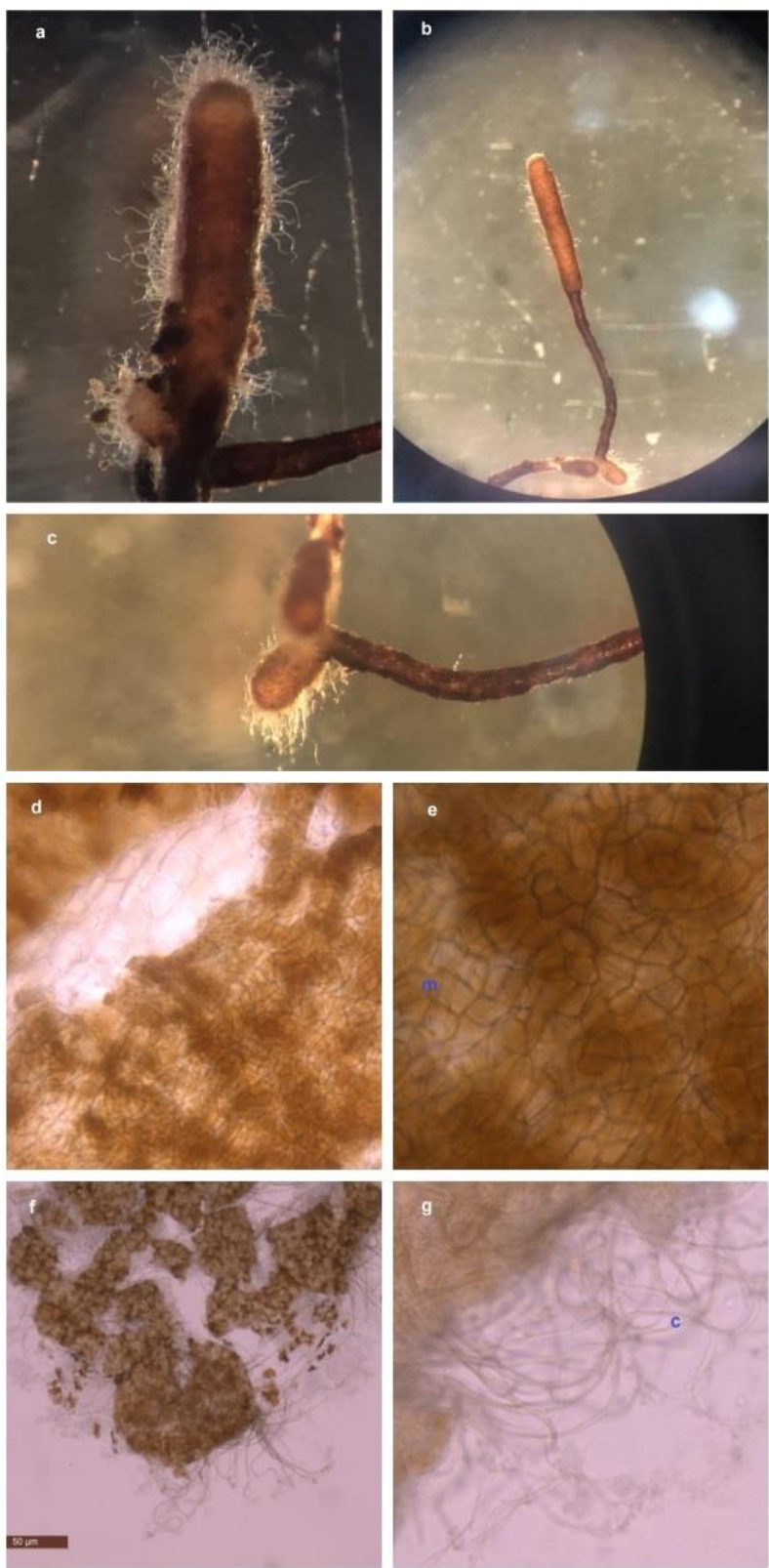

Figure 2. $(a, b, c)$ The mycorrhizal structure in the roots, $(\mathrm{d}, \mathrm{e}, \mathrm{f}, \mathrm{g})$ The mantle (m) sheath and the cystidia (c)

\section{References}

Avis, P.G., McLaughlin, D.J., Dentinger, B.C., Reich, P.B., 2003. Long-term increase in nitrogen supply alters above- and belowground ectomycorrhizal communities and increases the dominance of Russula spp. in a temperate oak savanna. New Phytol, 160:239-253.

Agerer, R., 1991. Characterization of ectomycorrhiza. In: Norris JR, Read DJ, Varma A (eds) Techniques for the study ofmycorrhiza. Methods Microbiol, 23:25-73.

Benucci, G.M.N., Bonito, G., Falini, L.B., Bencivenga, M., 2012a Mycorrhization of Pecan trees (Carya illinoinensis) with commercial truffle species: Tuber aestivum Vittad. and Tuber borchii Vittad. Mycorrhiza, 22(5): 383-392.

Benucci, G.M.N., Bonito, G., Baciarelli Falini, L., Bencivenga, M., Donnini, D. 2012b. Truffles, timber, food, and fuel: sustainable approaches for multi-cropping truffles and economically important plants. In: Zambonelli A, Bonito G (eds) Edible ectomycorrhizal mushrooms. Springer-Verlag Berlin, Heidelberg, pp 265-280.

Bonito, G., Brenneman, T., Vilgalys, R., 2011a. Ectomycorrhizal fungal diversity in orchards of cultivated pecan (Carya illinoinensis; Juglandaceae). Mycorrhiza, 21(7): 601-612. doi:10.1007/s00572-011-0368-0.

Bonito, G., Trappe, J.M., Donovan, S., Vilgalys, R., 2011b. The Asian black truffle Tuber indicum can form ectomycorrhizas with North American host plants and complete its life cycle in non-native soils. Fungal Ecology, 4(1): 83-93. doi:10.1016/j.funeco.2010.08.003

Bonito, G., Smith, M.E., Brenneman, T., Vilgalys, R., 2012. Assessing ectomycorrhizal fungal spore banks of truffle producing soils with pecan seedling trap-plants. Plant Soil, 356: 357366. doi:10.1007/s11104-012-1127-5.

Chevalier, G., Frochot, H., 2002. La Truffe de Bourgogne (Tuber uncinatum Chatin). Editions Petrarque, Levallois-Perret Cedex.

Donnini, D., Gargano, M.L., Perini, C., Savino, E., Murat, C., Di Piazza, S., Altobelli, E., Salerni, E., Rubini, A., Rana, G.L., Bencivenga, M., Venanzoni, R., Zambonelli, A., 2013. Wild and cultivated mushrooms as a model of sustainable development. Plant Biosystems-An International Journal Dealing with all Aspects of Plant Biology, 147(1): 226-236. doi: $10.1080 / 11263504.2012 .754386$

Fischer, C., Colinas, C., 1996. Methodology for the certification of Quercus ilex seedlings inoculated with Tuber melanosporum for commercial application. First International Conference in Mycorrhizae, August 4-9, Berkeley, California, USA.1-9.

Figliuolo, G., Trupo, G., Mang, S., 2013. A realized Tuber magnatum niche in the upper Sinni area (south Italy). Open Journal of Genetics, 3(2):102

Gardea, A.A., Martínez-Téllez, M.A., Yahia, E.M., 2011. Pecan (Carya illinoiensis (Wangenh.) K. Koch.). In: Yahia EM (ed) Postharvest biology and technology of tropical and subtropical fruits. Woodhead Publishing Ltd, Cambridge pp.143-165, $166 \mathrm{e}$.

Hall, I., Brown, G., Zambonelli, A., 2007. Taming the truffle. The history, lore, and science of the ultimate mushroom. Portland,Oregon, Timberpress.

Hanlin, R.T., Wu, M., Brenneman, T.B., 1989. The occurrence of Tuber texense in Georgia. Mycotaxon, 34: 387-394.

Hanson, A.M., Hodge, K., Porter, L.M., 2003. Mycophagy among primates. Mycologist, 17(1): 6-10. https://doi.org/10.1017/ S0269915X0300106X.

Heimsch, C., 1958. The first recorded truffle from Texas. Mycologia, 50(5): 657-660.

Jumpponen, A., Jones, K.L., 2010. Massively parallel 454 sequencing indicates hyperdiverse fungal communities in temperate Quercus macrocarpa phyllosphere. New Phytologist, 184(2): 438-448. doi:10.1111/j.14698137.2009.02990.x 
Marzolo, G., 2015. Pecans. 2017 Ag Marketing Resource Center, Iowa State University. http://www.agmrc.org/ commoditiesproducts/ nuts/pecans/, Accessed: 12.06.2017

Mello, A., Murat, C., Bonfante, P., 2006. Truffles:muchmore than a prized and local fungal delicacy. FEMS Microbiology Letters, 260(1): 1-8.

Özderin, S., Y1lmaz, F., All, H., 2018. Determining mycorrhiza rate in some oak species inoculated with Tuber aestivum Vittad. (summer truffle). Turkish Journal of Forestry, 19(3): 226-232

Reyna, S., Boronat, T., Palomar, E., 2000. Control de calidad en la planta micorrizada con Tuber melanosporum Vitt. producida por viveros comerciales. Montes, 61:17-24.

Reyna, S., Garcia-Barreda, S., 2014. Black truffle cultivation: a global reality. Forest Systems, 23: 317-328. doi: 10.5424/fs/2014232-04771

Reyna Doménech, S., 2007. Truficultura. Fundamentos y técnicas. Ediciones Mundi-Prensa, Madrid

Riousset, L., Riousset, G., Chevalier, G., Bardet, M.C., 2001. Truffes d'Europe et de Chine. INRA, Paris.

Selosse, M.A., Faccio, G., Scappaticci, G., Bonfante, P., 2004. Chlorophyllous and achlorophyllous specimens of Epipactis microphylla (Neottieae, Orchidaceae) are associated with ectomycorrhizal septomycetes, including truffles. Microbial Ecology, 47(4): 416-426.. doi: 10.1007/s00248-003-2034-3

Schickmann, S., Urban, A., Kräutler, K., Nopp-Mayr, U., Hackländer, K., 2012. The interrelationship of mycophagous small mammals and ectomycorrhizal fungi in primeval, disturbed and managed Central European mountainous forests. Oecologia, 170: 395-409. https:// doi.org/10.1007/s00442-0122303-2

Stobbe, U., Buntgen, U., Sproll, L., Tegel, W., Egli, S., Fink, S. 2012. Spatial distribution and ecological variation of rediscovered German truffle habitats. Fungal Ecology, 5(5):591599.
Thompson, T.E., Conner, P.J., 2012. Pecan. In Fruit Breeding, Handbook of Plant Breeding, Edited by M.L. Badenes, D.H. Byrne, Springer, New York, USA, 875p.

Trappe, J., Jumpponen, A.M., Cazares, E., 1996. Nats truffle and truffle-like fungi 5: Tuber lyonii (=T. texense), with a key to the spiny-spored Tuber species groups. Mycotaxon, 60:365372.

Trappe, J.M., Molina, R., Luoma, D.L., Cázares, E., Pilz, D., Smith, J.E., Castellano, M.A., Miller, L., Trappe, M.J., 2009. Diversity, ecology and conservation of the truffle fungi in forests of the Pacific northwest. US Dept. of Agriculture, Forest Service General Technical Report PNW-GTR-772. https://doi.org/10.2737/ PNW-GTR-772.

Trappe, J.M., Claridge, A., 2010. The hidden life of truffles: not just for gourmands, truffles play essential roles in the health of ecosystems. Scientific American, 302: 78-84. https://doi. org/10.1038/scientificamerican0410-78.

Venkatachalam, M., 2004. Chemical Composition of Select Pecan [Carya illinoinensis (Wangenh.) K. Koch]Varieties and Antigenic Stability of Pecan Proteins. Electronic Theses, Treatises and Dissertations. The Florida State University, College of Human Sciences, Florida, USA, 90p.

Venkatachalam, M., Kshirsagar, H.H., Seeram, N.P., Heber, D., Thompson, T.E., Roux, K.H., Sathe, S.K., 2007. Biochemical composition and immunological comparison of select pecan [Carya illinoinensis (Wangenh.) K. Koch] cultivars. Journal of Agricultural and Food Chemistry, 55(24): 9899-9907.

Yuanzhi, T., 2016, Method for cultivating wild truffles - Google Patents, (CN105349435A).

Zambonelli, A., Salomoni, S., Pisi, A., 1993. Caratterizzazione anatomomorfologica delle micorrize di Tuber spp. su Quercus pubescens Willd. Micol Ital., 3:73-90. 